\title{
Schedule V Substance
}

National Cancer Institute

\section{Source}

National Cancer Institute. Schedule V Substance. NCI Thesaurus. Code C48679.

A category of medically useful drugs that have less potential for abuse or addiction than those of Schedules I through IV. 